Hal : 52-63

\title{
Kajian:
}

Pembelajaran PPKn

\section{PERAN PEMERINTAH DAERAH DALAM PENCEGAHAN KEBAKARAN HUTAN DI KABUPATEN INDRAGIRI HILIR PROVINSI RIAU}

\author{
Rizana \\ Prodi Ilmu Hukum, Fakultas Hukum, Universitas Lancang Kuning \\ Email: rizana@unilak.ac.id
}

\begin{abstract}
Abstrak
Menurut Pasal 50 Ayat (3) Huruf d Undang-Undang Nomor 41 Tahun 1999 tentang Kehutanan ditegaskan bahwa setiap orang dilarang membakar hutan, tetapi dari hasil observasi yang dilakukan di Kabupaten Indragiri Hilir Provinsi Riau diperoleh informasi bahwa di Kabupaten Indragiri Hilir setiap tahun rutin terjadi kebakaran hutan. Hal ini membuktikan lemahnya kinerja Pemerintah Kabupaten Indragiri Hilir dalam mencegah terjadinya kebakaran hutan. Permasalahannya bagaimanakah peran pemerintah daerah dalam pencegahan kebakaran hutan di Kabupaten Indragiri Hilir Provinsi Riau? Metode yang digunakan dalam penelitian ini adalah penelitian hukum sosiologis. Hasil penelitian menjelaskan bahwa penegakan hukum terhadap tindak pidana pembakaran hutan di Kabupaten Indragiri Hilir adalah menurut Pasal 78 Ayat (3) Undang-Undang Nomor 41 Tahun 1999 tentang Kehutanan ditegaskan bahwa barang siapa yang dengan sengaja membakar hutan dapat diancam dengan pidana penjara paling lama 15 tahun dan denda paling banyak Rp 5.000.000.000,-. Pemerintah Kabupaten Indragiri Hilir dapat melakukan upaya pencegahan untuk meminimalisir terjadinya kebakaran hutan dengan melaksanakan penyuluhan hukum ke tengah-tengah masyarakat mengenai larangan membakar hutan berdasarkan UndangUndang Nomor 41 Tahun 1999 tentang Kehutanan dengan melibatkan pihak kepolisian dan masyarakat.
\end{abstract}

Kata kunci: Hukum, Kebakaran Hutan, Peran Pemerintah Daerah 


\section{Kajian:}

Pembelajoran PPKn

\section{PENDAHULUAN}

Hutan adalah suatu kesatuan ekosistem berupa hamparan lahan yang luas yang berisi sumber daya alam hayati yang didominasi oleh pepohonan dalam persekutuan alam lingkungannya yang tidak dapat dipisahkan antara yang satu dengan yang lainnya (Abdul Muis Yusuf \& Mohammad Taufik Makarao, 2011). Hutan sebagai karunia dan amanah dari Tuhan Yang Maha Esa yang dianugerahkan kepada bangsa Indonesia merupakan kekayaan alam yang tidak ternilai harganya. Hutan,selain merupakan unsur utama sistem penyangga kehidupan manusia, juga merupakan modal dasar pembangunan nasional yang memiliki manfaat nyata, baik manfaat ekologi, manfaat sosial budaya, maupun manfaat ekonomi.Oleh karena itu, pemanfaataannya harus dilakukan secara terencana, rasional, optimal, dan bertanggung jawab sesuai dengan kemampuan daya dukung serta memperhatikan kelestarian fungsi dan keseimbangan lingkungan hidup guna mendukung pengelolaan hutan dan pembangunan kehutanan yangberkelanjutan bagi kesejahteraan rakyat.

Pasal 33 Ayat (3) UndangUndang Dasar Negara Republik Indonesia Tahun 1945 menegaskan bahwa bumi, air, dan kekayaan alam yang terkandung di dalamnya dikuasai oleh negara dan dipergunakan untuk sebesar-besarnya kemakmuran rakyat.Dalam rangka memperoleh manfaat yang optimal dari hutan bagi kesejahteraan rakyat, maka pada prinsipnya hutan dapat dimanfaatkan dengan memperhatikan sifat, karakteristik, dan kerentaannya serta tidak dibenarkan untuk mengubah fungsi pokok hutan, yaitu fungsi konservasi, fungsi lindung, dan fungsi produksi (Salim H.S., 2013).Hutan merupakan salah satu kekayaan sumber daya alam bangsa Indonesia yang harus dijaga kelestariannya agar dapat diwariskan dari generasi ke generasi.

Menurut Pasal 50 Ayat

Huruf d Undang-Undang Nomor 41 Tahun 1999 tentang Kehutanan 


\section{Kajian:}

Pembelajoran PPKn

ditegaskan bahwa setiap orang dilarang membakar hutan. Dari hasil observasi yang dilakukan di Kabupaten Indragiri Hilir Provinsi Riau, peneliti memperoleh informasi dari Badan Penanggulangan Bencana Daerah (BPBD) Kabupaten Indragiri Hilir bahwa di Kabupaten Indragiri Hilir setiap tahun rutin terjadi kebakaran hutan, baik yang dilakukan oleh masyarakat maupun pihak perusahaan.

Penguasaan sumber daya hutan oleh negara memberi wewenang kepada pemerintah untuk mengatur dan mengurus segala sesuatu yang berkaitan dengan hutan, kawasan hutan, dan hasil hutan; menetapkan kawasan hutan dan/atau mengubah status kawasan hutan; mengatur dan menetapkan hubungan hukum antara orang dan hutan atau kawasan hutan dan hasil hutan; serta mengatur perbuatan hukum mengenai kehutanan. Artinya, pemerintah pemerintah bertanggung jawab penuh menjaga kelestarian hutan. Kebakaran hutan yang rutin terjadi setiap tahunnya di Kabupaten Indragiri Hilir menunjukkan lemahnya peran pemerintah dalam pencegahan tindak pidana pembakaran hutan.

Dari pendahuluan yang telah dijelaskan di atas, maka permasalahan yang akan dibahas dalam penelitian ini adalah bagaimanakah peran pemerintah daerah dalam pencegahan kebakaran hutan di Kabupaten Indragiri Hilir Provinsi Riau.

\section{METODE PENELITIAN}

Penelitian hukum adalah suatu kegiatan ilmiah yang didasarkan pada metode, sistematika, dan pemikiran tertentu yang bertujuan untuk mempelajari satu atau beberapa gejala hukum tertentu dengan jalan menganalisanya (Soerjono Soekanto, 2007). Metode yang digunakan dalam penelitian ini adalah penelitian hukum sosiologis. Penelitian hukum sosiologis adalah suatu penelitian yang dilakukan dengan cara menjelaskan pelaksanaan peraturan perundangundangan terhadap permasalahan yang ada di masyarakat (Zainuddin Ali, 2013). 


\section{Kajian:}

Pembelajaran PPKn

Sumber data yang digunakan dalam penelitian ini adalah data primer dan data sekunder. Data primer yaitu data yang diperoleh langsung dari hasil observasi, wawancara, dan kuisioner di lokasi penelitian; sedangkan data sekunder yaitu data yang diperoleh dari jurnaljurnal ilmiah, literatur hukum, dan peraturan perundang-undangan. Responden dalam penelitian ini adalah Badan Penanggulangan Bencana Daerah (BPBD) Kabupaten Indragiri Hilir. Teknik pengumpulan data yang digunakan dalam penelitian ini adalah observasi, wawancara, kuisioner, dan studi kepustakaan. Teknik analisis data yang digunakan dalam penelitian ini adalah analisis kualitatif.

\section{HASIL PENELITIAN DAN PEMBAHASAN}

Hutan merupakan salah satu kekayaan sumber daya alam bangsa Indonesia yang dapat dimanfaatkan dalam kehidupan sehari-hari. Oleh karena itu, hutan harus dijaga kelestariannya agar dapat diwariskan dari generasi ke generasi. Sejalan dengan itu, menurut Pasal 50 Ayat (3) Huruf d Undang-Undang Nomor 41 Tahun 1999 tentang Kehutanan ditegaskan bahwa setiap orang dilarang membakar hutan. Ketentuan tersebut dapat diartikan bahwa meskipun hutan dapat dimanfaatkan dalam kehidupan sehari-hari, tetapi setiap orang dilarang membakar hutan untuk memperoleh manfaatnya agar kelestarian hutan tetap terjaga.

Hutan yang ada Indonesia merupakan salah satu hutan tropis terluas di dunia sehingga keberadaannya menjadi tumpuan bagi keberlangsungan kehidupan bangsa-bangsa di dunia, terutama dalam hal mengurangi dampak perubahan iklim global. Oleh karena itu, pemanfaataan hutan harus dilakukan secara terencana, rasional, optimal, dan bertanggung jawab sesuai dengan kemampuan daya dukung serta memperhatikan kelestarian fungsi dan keseimbangan lingkungan hidup guna mendukung pengelolaan hutan dan pembangunan kehutanan yang berkelanjutan bagi kemakmuran rakyat. 


\section{Kajian:}

Pembelajaran PPKn

Implementasi Undang-Undang

Nomor 41 Tahun 1999 tentang

Kehutanan terhadap kebakaran hutan

di Kabupaten Indragiri Hilir Provinsi

Riau belum berjalan sebagaimana yang diharapkan. Hal ini dikarenakan setiap tahunnya rutin terjadi kebakaran hutandi Kabupaten Indragiri Hilir. Pada tahun 2017, terjadi kebakaran hutan seluas lebih kurang 1,5 Ha yang berlokasi di Desa Teluk Jira Kecamatan Tempuling Kabupaten Indragiri Hilir yang dilakukan oleh tersangka bernama Afrianto bin Sutikno. Selanjutnya, pada tahun 2018 juga terjadi kebakaran hutan seluas lebih kurang 50 Ha yang berlokasi di Desa Panglima Raja Kecamatan Concong Kabupaten Indragiri Hilir.

Pada tahun 2019 ternyata masih terjadi kebakaran hutan di Kabupaten Indragiri Hilir. Kebakaran hutan tersebut tidak hanya terjadi di satu titik saja, tetapi juga terjadi di beberapa titik secara bersamaan karena terjadi pada musim kemarau, yaitu di Kecamatan Tempuling, Kecamatan Enok, Kecamatan Kuindra, Kecamatan Batang Tuaka,
Kecamatan Gaung, dan Kecamatan Keritang dengan luas area yang terbakar diperkirakan lebih kurang seluas puluhan hektar. Kasus kebakaran hutan yang terjadi di Kabupaten Indragiri Hilir saat ini masih dalam proses penyilidikan oleh pihak kepolisian dan instansi yang berwenang lainnya.

Peraturan perundang-undangan di Indonesia sebenarnya ada mengecualikan bahwa perbuatan membakar hutan dibolehkan dengan mempertimbangkan kearifan lokal (Hendra Eriant Dikser, 2017).PadaPasal 69 Ayat Undang-Undang Nomor 32 Tahun 2009 tentang Perlindungan dan Pengelolaan Lingkungan Hidup disebutkan bahwa ketentuan yang menegaskan setiap orang dilarang melakukan pembukaan lahan dengan cara membakar sebagaimana yang diatur pada Pasal 69 Ayat (1) Huruf $\mathrm{h}$ undang-undang tersebut wajib memperhatikan dengan sungguhsungguh kearifan lokal di daerah masing-masing.

Pemerintah Provinsi Riau dalam mengendalikan kebakaran 


\section{Kajian:}

Pembelajaran PPKn

hutan belum berjalan dengan efektif karena hanya diarahkan pada proses pemadaman terhadap hutan yang terbakar dalam rangka mencegah terjadinya kabut asap. Pemerintah Provinsi Riau sampai saat ini belum menemukan solusi yang ideal untuk mencegah kebakaran hutan yang rutin terjadi setiap tahunnya. Selain itu, alokasi anggaran dana yang disediakan untuk penanganan kebakaran hutan jumlahnya terbatas sehingga Pemerintah Provinsi Riau harus menunggu bantuan dana dan peralatan dari pemerintah pusat.Dengan hamparan hutan gambut yang luas, Pemerintah Provinsi Riau seharusnya mengalokasikan anggaran dana yang besar untuk mengantisipasi terjadinya kebakaran hutan, khususnya pada musim kemarau (Geovani Meiwanda, 2016).

Adapun hambatan dalam implementasi Undang-Undang Nomor 41 Tahun 1999 tentang Kehutanan terhadap kebakaran hutan di Kabupaten Indragiri Hilir adalah masih minimnya pemahaman masyarakat mengenai manfaat hutan untuk jangka panjang. Sebagian besar masyarakat hanya beranggapan bahwa hutan merupakan salah satu kekayaan sumber daya alam yang harus dikelola untuk meningkatkan perekonomiannyapada saat itu saja, tanpa mempertimbangkan bahwa hutan merupakan paru-paru dunia sebagai penghasil udara segar yang baik untuk kesehatan manusia dan berguna untuk menyeimbangkan keadaan iklim global, sehingga hutan harus dijaga kelestariannya dan diwariskan untuk generasi berikutnya.

Hambatan lainnya dalam implementasi Undang-Undang Nomor 41 Tahun 1999 tentang Kehutanan terhadap kebakaran hutan di Kabupaten Indragiri Hilir adalah masih lemahnya penegakan hukum pada kasus kebakaran hutan. Hal ini dikarenakan meskipun telah ada Undang-Undang Nomor 41 Tahun 1999 tentang Kehutanan sebagai dasar hukum yang melarang setiap orang untuk membakar hutan, tetapi kebakaran hutan masih rutin terjadi setiap tahunnya di Kabupaten Indragiri Hilir. Menurut Undang- 


\section{Kajian:}

\section{Pembelajaran PPKn}

Undang Nomor 41 Tahun 1999 tentang kehutanan, membakar hutan merupakan tindak pidana, sehingga di dalam Undang-Undang Nomor 41 Tahun 1999 tentang Kehutanan juga diatur mengenai sanksi pidana yang tegas bagi siapa saja yang melakukan tindak pidana pembakaran hutan.

Dalam rangka mewujudkan efektivitas implementasi UndangUndang Nomor 41 Tahun 1999 tentang Kehutanan di Kabupaten Indragiri Hilir, dibutuhkan adanya penegakan hukum yang tegas terhadap siapa saja yang melakukan tindak pidana pembakaran hutan. Akan tetapi, penegakan hukum tidak dapat berjalan sebagaimana yang dicita-citakan karena terdapat faktorfaktor yang mempengaruhi proses penegakan hukum. Menurut Soerjono Soekanto, faktor-faktor yang mempengaruhi penegakan hukum ada lima, yaitu faktor hukum itu sendiri (undang-undang), faktor penegak hukum, faktor sarana yang mendukung penegakan hukum, faktor masyarakat, dan faktor kebudayaan. Kelima faktor tersebut saling berkaitan erat karena merupakan esensi dari penegakan hukum dan tolak ukur dari efektivitas penegakan hukum (Soerjono Soekanto, 2013).

Penegakan hukum terhadap tindak pidana pembakaran hutan di Kabupaten Indragiri Hilir menurut Undang-Undang Nomor 41 Tahun 1999 tentang Kehutanan adalah pada Pasal 78 Ayat (3) Undang-Undang Nomor 41 Tahun 1999 tentang Kehutanan ditegaskan bahwa barang siapa yang dengan sengaja membakar hutan dapat diancam dengan pidana penjara paling lama 15(lima belas) tahun dan denda paling banyak Rp5.000.000.000,(lima miliar rupiah). Selanjutnya, pada Pasal 78 Ayat (4) UndangUndang Nomor 41 Tahun 1999 tentang Kehutanan juga ditegaskan bahwa barang siapa yang karena kelalaiannya menyebabkan hutan terbakar dapat diancam dengan pidana penjara paling lama 5(lima) tahun dan denda paling banyak Rp1.500.000.000,- (satu miliar lima ratus juta rupiah). Selain itu, apabila tindak pidana pembakaran hutan yang terjadi di Kabupaten Indragiri 


\section{Kajian:}

\section{Pembelajoran PPKn}

Hilir dilakukan oleh badan hukum atau badan usaha dan/atau atas nama badan hukum atau badan usaha, maka tuntutan pidananya akan dijatuhkan kepada pengurus badan hukum atau badan usaha tersebut dengan sanksi pidana sebagaimana yang telah ditegaskan pada Pasal 78 Ayat (3) Undang-Undang Nomor 41 Tahun 1999 tentang Kehutanan di atas, lalu sanksi pidananya ditambah dengan 1/3 (sepertiga) dari sanksi pidana pada Pasal 78 Ayat (3) Undang-Undang Nomor 41 Tahun 1999 tentang Kehutanan tersebut.

Apabila tindak pidana pembakaran hutan dilakukan oleh badan hukum atau badan usaha dan/atau atas nama badan hukum atau badan usaha, maka dapat digunakan prinsip strict liability, yaitu pertanggungjawaban dari pelaku tindak pidana atas kejahatan yang telah dilakukannya. Prinsip strict liability pernah diterapkan oleh hakim pada putusan terhadap kasus tindak pidana pembakaran hutan di Provinsi Riau yang dilakukan oleh PT Adei Plantation pada tahun 2014 (Eko Ardiansyah Pandiangan, 2016).
Penegakan hukum terhadap pelaku tindak pidana pembakaran hutan sebenarnya merupakan langkah terakhir yang dilakukan oleh pemerintah maupun aparatur penegak hukum. Dengan telah terjadinya kebakaran hutan yang rutin terjadi setiap tahunnya di Kabupaten Indragiri Hilir sebenarnya dapat dijadikan dasar untuk menilai lemahnya kinerja pemerintah daerah, yaitu Pemerintah Kabupaten Indragiri Hilir.

Pemerintah Kabupaten Indragiri Hilir seharusnya mampu mencari dan menemukan akar permasalahan yang menyebabkan kebakaran hutan menjadi rutinitas yang terjadi setiap tahunnya di Kabupaten Indragiri Hilir. Artinya, kebakaran hutan sebenarnya dapat dicegah jika diketahui penyebabnya.

Pemerintah mempunyai kewenangan untuk memberikan izin dan hak kepada pihak lain untuk melakukan kegiatan di bidang kehutanan. Pemanfaatan hutan dilakukan dengan pemberian izin pemanfaatan kawasan, izin pemanfaatan jasa lingkungan, izin 


\section{Kajian:}

Pembelajaran PPKn

pemanfaatan hasil hutan kayu dan izin pemanfaatan hasil hutan bukan kayu, serta izin pemungutan hasil hutan kayu dan bukan kayu (Supriadi, 2010). Akan tetapi, kebijakan di bidang kehutanan selain merupakan salah satu kebijakan strategis yang bersifat nasional, juga merupakan kebijakan yang erat kaitannya dengan permasalahan lingkungan internasional, seperti terjadinya kebakaran hutan yang menimbulkanpolusi udara berupa kabut asap yang sangat berbahaya bagi kesehatan yang dapat menyebar luas melewati batas negara hingga ke Malaysia dan Singapura. Hal ini dikarenakan Kabupaten Indragiri Hilir berbatasan langsung dengan Malaysia dan Singapura.

Akhir-akhir ini, tindak pidana pembakaran hutan semakin meluas dan kompleks. Pembakaran hutan terjadi tidak hanya pada Hutan Produksi, tetapi juga telah merambah ke Hutan Lindung dan Hutan Konservasi. Bahkan, pembakaran hutan juga terjadi pada lahan-lahan kecil yang ada di tengah-tengah masyarakat. Upaya untuk mencegah kebakaran hutan sesungguhnya telah lama dilakukan oleh pemerintah, tetapi belum berjalan secara efektif dan belum menunjukkan hasil yang optimal.

Pemerintah Kabupaten Indragiri Hilir dapat melakukan upaya pencegahan untuk meminimalisir terjadinya tindak pidana pembakaran hutan dengan melaksanakan penyuluhan hukum ke tengah-tengah masyarakat mengenai larangan membakar hutan berdasarkan Undang-Undang Nomor 41 Tahun 1999 tentang Kehutanan, sanksi pidana bagi pelaku tindak pidana pembakaran hutan, serta bahaya kebakaran hutan bagi kehidupan.Agar pencegahan tersebut lebih efektif, Pemerintah Kabupaten Indragiri Hilir dapat bekerja sama dengan pihak kepolisian untuk memberikan penyuluhan hukum kepada masyarakat. Penguatan peran pihak kepolisian tersebut secara psikologis dapat meyakinkan masyarakat bahwa membakar hutan merupakan tindak pidana.

Selain itu, Pemerintah Kabupaten Indragiri Hilir dapat 


\section{Kajian:}

Pembelajaran PPKn

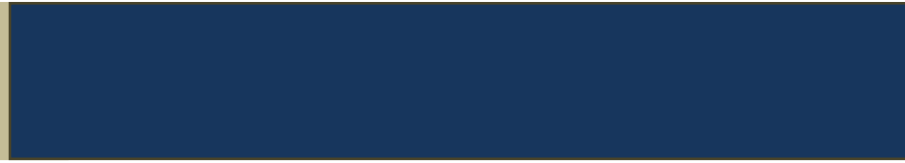

meningkatkan peran masyarakat dalam menjaga kelestarian hutan yang ada di sekitarnya. Menurut Undang-Undang Nomor 41 Tahun 1999 tentang Kehutanan disebutkan bahwa masyarakat berkewajiban untuk ikut memelihara dan menjaga hutan dari gangguan dan perusakan yang dilakukan oleh orang-orang yang tidak bertanggung jawab. Salah satu bentuk peningkatan peran masyarakat untuk menjaga kelestarian hutan adalah adanya penghargaan dari Pemerintah Kabupaten Indragiri Hilir kepada masyarakat, baik perorangan maupun kelompok masyarakat, apabila mengetahui dan melaporkan pelaku tindak pidana pembakaran hutan tersebut.

Pemerintah Kabupaten Indragiri Hilir juga dapat mengadopsi kebijakan Dinas Kehutanan Provinsi Riau untuk mencegah terjadinya kebakaran hutan di Kabupaten Indragiri Hilir. Adapun kebijakan tersebut yaitu:

1. Memantapkan kawasan hutan sesuai dengan fungsinya.
2. Meningkatkan rehabilitasi hutan dan lahan serta perhutanan sosial.

3. Mengoptimalkan perlindungan dan konservasi hutan.

4. Mengoptimalkan pemanfaatan hutan yang berwawasan lingkungan.

5. Menguatkan kelembagaan dan kewirausahaan masyarakat sekitar hutan.

6. Meningkatkan peran swasta kehutanan dalam pembangunan.

\section{KESIMPULAN}

Menurut Pasal 50 Ayat (3) Huruf d Undang-Undang Nomor 41 Tahun 1999 tentang Kehutanan ditegaskan bahwa setiap orang dilarang membakar hutan, tetapi dari hasil observasi yang dilakukan di Kabupaten Indragiri Hilir Provinsi Riau diperoleh informasi bahwa di Kabupaten Indragiri Hilir setiap tahun rutin terjadi kebakaran hutan. Hal ini membuktikan lemahnya kinerja Pemerintah Kabupaten Indragiri Hilir dalam mencegah terjadinya kebakaran hutan. Penegakan hukum terhadap tindak pidana pembakaran hutan di Kabupaten Indragiri Hilir adalah 


\section{Kajian:}

Pembelajaran PPKn

menurut Pasal 78 Ayat (3) Undang-

Undang Nomor 41 Tahun 1999

tentang Kehutanan ditegaskan bahwa barang siapa yang dengan sengaja membakar hutan dapat diancam dengan pidana penjara paling lama 15 tahun dan denda paling banyak Rp5.000.000.000,-.Pemerintah

Kabupaten Indragiri Hilir dapat melakukan upaya pencegahan untuk meminimalisir terjadinya kebakaran hutan dengan melaksanakan penyuluhan hukum ke tengah-tengah masyarakat mengenai larangan membakar hutan berdasarkan Undang-Undang Nomor 41 Tahun 1999 tentang Kehutanan dengan melibatkan pihak kepolisian dan masyarakat.

\section{DAFTAR PUSTAKA}

Abdul Muis Yusuf dan Mohammad Taufik Makarao.Hukum

Kehutanan $d i$

Indonesia.Jakarta: Rineka Cipta, 2011.

Eko Ardiansyah Pandiangan, Erdianto, dan Ledy Diana.Penerapan Prinsip Strict Liability dalam Pertanggungjawaban Korporasi yang Dianggap Bertanggung Jawab atas
Kebakaran Hutan di Provinsi Riau. Jurnal Online Mahasiswa (JOM) Fakultas Hukum Universitas Riau, Volume III, Nomor 2, 2016.

Geovani Meiwanda.Kapabilitas Pemerintah Daerah Provinsi Riau; Hambatan dan Tantangan Pengendalian Kebakaran Hutan dan Lahan. Jurnal Sosial Politik, Volume 19, Nomor 3, 2016.

Hendra Eriant Dikser, Erdianto, dan Widia Edorita.Analisis Yuridis terhadap Pengecualian Pembakaran Lahan dan Hutan Berdasarkan Pasal 69 Ayat (2) Undang-Undang Nomor 32 Tahun 2009 tentang Perlindungan dan Pengelolaan Lingkungan Hidup. Jurnal Online Mahasiswa (JOM) Fakultas Hukum Universitas Riau, Volume IV, Nomor 2, 2017.

Salim H.S.Dasar-dasar Hukum Kehutanan.Jakarta: Sinar Grafika, 2013.

Soerjono Soekanto. Pengantar Penelitian Hukum.Jakarta: UI Press, 2007.

Soerjono Seokanto.Faktor-faktor yang Mempengaruhi Penegakan Hukum.Jakarta: Rajawali Pers, 2013.

Supriadi.Hukum Kehutanan dan Hukum Perkebunan di 


\section{Kajian:}

Pembelajaran PPKn

Indonesia.Jakarta: $\quad$ Sinar Grafika, 2010.

Undang-Undang Republik Indonesia Nomor 41 Tahun 1999 tentang Kehutanan. Lembaran Negara Republik Indonesia Tahun 1999 Nomor 167. Tambahan Lembaran Negara Republik Indonesia Nomor 3888.

Wartiningsih.Pidana Kehutanan; Keterlibatan dan Pertanggungjawaban

Penyelenggara Kebijakan Kehutanan.Malang: Setara Press, 2014.

Zainuddin Ali.Metode Penelitian Hukum.Jakarta: Sinar Grafika, 2013. 